\title{
Decontamination of a rotating cutting tool during operation by means of atmospheric pressure plasmas
}

Leipold, Frank; Kusano, Yukihiro; Hansen, F.; Jacobsen, T.

Published in:

Proceedings (CD-ROM)

Publication date:

2009

Document Version

Publisher's PDF, also known as Version of record

Link back to DTU Orbit

Citation (APA):

Leipold, F., Kusano, Y., Hansen, F., \& Jacobsen, T. (2009). Decontamination of a rotating cutting tool during operation by means of atmospheric pressure plasmas. In Proceedings (CD-ROM) ICPIG.

\section{General rights}

Copyright and moral rights for the publications made accessible in the public portal are retained by the authors and/or other copyright owners and it is a condition of accessing publications that users recognise and abide by the legal requirements associated with these rights.

- Users may download and print one copy of any publication from the public portal for the purpose of private study or research.

- You may not further distribute the material or use it for any profit-making activity or commercial gain

- You may freely distribute the URL identifying the publication in the public portal

If you believe that this document breaches copyright please contact us providing details, and we will remove access to the work immediately and investigate your claim. 


\title{
Decontamination of a rotating cutting tool during operation by means of atmospheric pressure plasmas
}

\author{
F. Leipold ${ }^{* 1}$, Y. Kusano ${ }^{1}$, F. Hansen ${ }^{2}$, and T. Jacobsen ${ }^{2}$ \\ ${ }^{I}$ Risø National Laboratory for Sustainable Energy, Technical University of Denmark, DK-4000 Roskilde, \\ Denmark \\ 2 Danish Meat Research Institute DK-4000 Roskilde, Denmark
}

\begin{abstract}
The decontamination of a rotating cutting tool used for slicing in the meat industry by means of atmospheric pressure plasmas is investigated. The target is Listeria monocytogenes, a bacterium which causes listeriosis and can be found in plants and food. The non-pathogenic species, Listeria innocua, is used for the experiments. A rotating knife was inoculated with Listeria innocua. The surface of the rotating knife was partly exposed to an atmospheric pressure dielectric barrier discharge operated in air, where the knife itself served as a ground electrode. The rotation of the knife ensures a treatment of the whole cutting tool. A $\log 5$ reduction of Listeria innocua is obtained after $340 \mathrm{~s}$ of plasma operation. The temperature of the knife after treatment was found to be below $30^{\circ} \mathrm{C}$. The design of the setup allows a decontamination during slicing operation.
\end{abstract}

\section{Introduction}

Plasma technology has been shown to successfully replace conventional sterilization methods such as autoclaving, ethylene oxide (EtO) treatment and ionizing radiation (electron beam, gamma radiation). Especially non-thermal plasma, which operates at temperatures close to room temperature has gained considerable interest, as it has significant advantages compared to conventional sterilization methods: it is non-destructive to heat sensitive material, toxic chemicals like EtO are avoided, it does not degrade bulk properties of the exposed material during treatment. Several mechanisms were initially suspected for destruction of bacteria and spores: reaction with chemically reactive species (like free radicals), electrical interaction and sputtering with charged particles, and exposure to UV radiation. Inactivation of bacteria by means of chemically reactive species has been observed by many groups [1-13]. Atomic oxygen, ozone, hydroxyl, peroxyl, and $\mathrm{NO}_{\mathrm{x}}$ radicals are some of the species with demonstrated effects on cells [4]. Montie et al. [8] considered membrane lipid alteration caused by fatty acid peroxide formation and protein oxidation as a possible path to affect the cell. In addition, chemical etching can be expected by reactive oxygen radicals [12, 13]. Mendis et al. [2, 7] suggested that charged particles can accumulate on the outer cell membrane. Electrostatic forces can then lead to rupture of the cell membrane and subsequently cause cell death. Cell rupture was observed for $E$. coli, but not for $B$. subtilis. A possible explanation is that the electrostatic forces are not strong enough to cause rupture of spore shells [4, 7]. UV radiation can affect the DNA of a cell so that the cell is not able to replicate, eventually leading to the death of the cell. UV radiation has been found to be partly responsible for the damage to cells when low pressure plasmas are used for sterilization [14-16]. In contrast, UV exposure was found to play a minor role in atmospheric pressure plasma sterilization $[2,8,10$, 11]. Listeria monocytogenes is a bacterium which can be found in plants and food and is known to cause a serious disease (listeriosis) in humans, especially the elderly and immunocompromised. Also pregnant women are especially prone to $L$. monocytogenes infection, which leads to damage or even death of the foetus. Research has been done to investigate the inactivation of Listeria using plasmas or reactive species which can be generated in a plasma [17-22]. The methods involve direct treatment, where the contaminated sample is exposed to the plasma $[17,18]$ and remote treatment, where the contaminated surface is exposed to the reactive species $\left(\mathrm{O}_{3}, \mathrm{NO}\right)$ generated in a plasma [1921]. The objective of this investigation is to demonstrate the inactivation of Listeria by direct treatment with an atmospheric pressure plasma on the stainless steel surface of a rotating cutting tool used in an industrial meat slicing unit. Listeria innocua is used for this research as a non-pathogenic representative.

\footnotetext{
* Email: leip@risoe.dtu.dk
} 


\section{Experimental Setup}

The surface of a rotating knife (see Figure 1) will be exposed to a plasma generated by a dielectric barrier discharge (DBD). The DBD consists of the knife as ground electrode and an aluminum electrode. The aluminum electrode is water cooled. A ceramic plate $\left(\mathrm{Al}_{2} \mathrm{O}_{3}\right)$ in contact with the aluminum electrode serves as dielectric barrier between the electrode and the knife. The knife has a diameter of approximately $45 \mathrm{~cm}$ and the powered aluminum electrode has a size of $100 \mathrm{~mm} \times 100 \mathrm{~mm}$. The distance between ceramic plate and knife varies between $2 \mathrm{~mm}$ and 4 $\mathrm{mm}$, because the surface of the knife forms a shallow cone and the ceramic sheet is flat. The operation gas is ambient air at atmospheric pressure. Applying a high AC voltage between the electrode and the knife generates a plasma between the electrode and the surface of the knife. The rotation speed of the knife during experiments is $3.4 \mathrm{~s}$ per revolution. For these experiments, only one side of the knife is considered, but for industrial applications, this technique can easily be applied to both sides. The discharge power was set to $0.36 \mathrm{~kW}$. The temperature of the knife was measured by means of a thermo-couple element and was found to be below $30^{\circ} \mathrm{C}$. The ozone concentration was measured by means of UV absorption spectroscopy and was found to be below $2 \mathrm{ppm}$. The operation time of the unit was varied between $34 \mathrm{~s}$ and $340 \mathrm{~s}$. The ratio between the discharge area and the plasma overlayed area of the knife during one revolution is $12.2 \%$. Therefore, the exposure time in average is only $12.2 \%$ of the operation time. The inoculation and evaluation procedure is described in section 3. A photo of the experimental setup is shown in Figure 1.

\section{Materials and Methods}

Initially the knife was inoculated by evenly spraying approximately $240 \mu \mathrm{l}$ of a Listeria innocua inoculum $\left(5 \times 10^{8} \mathrm{cfu} / \mathrm{ml}\right)$ onto the surface of the slicing knife. The inoculum was prepared by culturing the $L$. innocua (Danish Meat Research Institute (DMRI), strain 0011) in BHI (OXOID CM0225) for 18 - 20 hours at $30^{\circ} \mathrm{C}$. Afterwards the overnight culture was diluted $1: 10$ in $0.85 \% \mathrm{NaCl}$. After the plasma treatment, the knife was sampled using sterile, gauze swabs $(100 \mathrm{~mm} \times 100 \mathrm{~mm}$ Cutisoft Cotton, BSN Medical 72227-09) moistened with approx. $5 \mathrm{ml}$ FKP $(0.85 \% \mathrm{NaCl}+0.1 \%$ peptone). The surface of the knife was wiped with the gauze swab by pressing it firmly on to the knife while rotating it one revolution. Afterwards the swab was placed in a stomacher bag and transported from Risø to DMRI in a cooling box at approx $4^{\circ} \mathrm{C}$. Each plasma treatment was done in 4 replicates. Between each sampling, the knife was disinfected by wiping the surface in $70 \%$ ethanol. In the laboratory (a few hours later), $25 \mathrm{ml} 0.85 \% \mathrm{NaCl}$ was added to each stomacher bag and gauze swab, and treated for $60 \mathrm{~s}$ in a stomacher. The initial suspension was afterwards diluted 10-fold in FKP. For enumerating of Listeria, $0.1 \mathrm{ml}$ from the initial suspension and $0.1 \mathrm{ml}$ of relevant dilutions were spread onto Oxford agar (OXOID CM856 + SR206) using a sterile drigalsky spatula. The Oxford agar plates were incubated at $37^{\circ} \mathrm{C}$ for 2 to 3 days and subsequently the number of typical colonies was recorded.

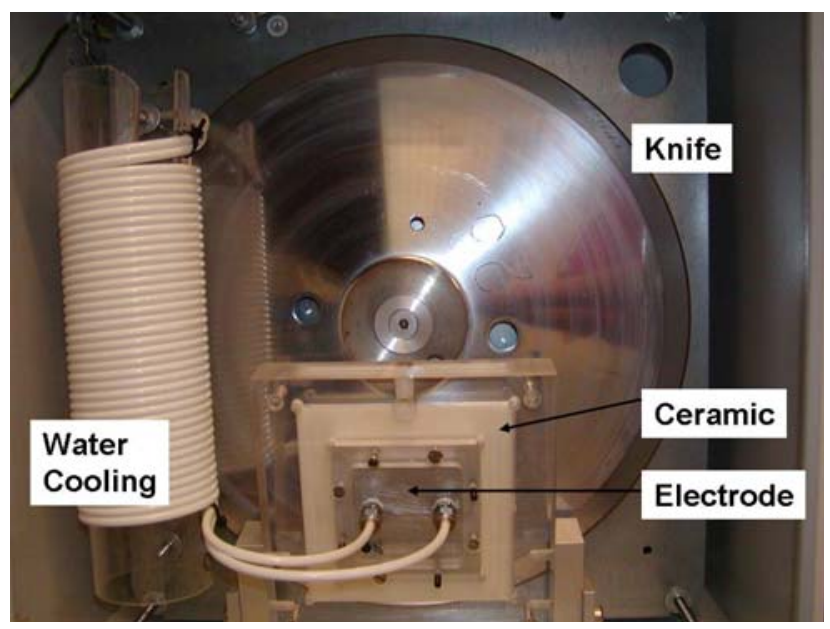

FIG. 1: Photography of the experimental setup. The electrode consists of an aluminum plate with a size of $100 \mathrm{~mm} \times 100 \mathrm{~mm}$. The Ceramic, $\mathrm{Al}_{2} \mathrm{O}_{3}$, is in contact with the electrode and serves as dielectric layer between the electrode and the knife.

\section{Results and Discussion}

The results show an almost negligible inactivation of L. innocua below an operation time of $34 \mathrm{~s}$. A fairly high inactivation (log 4) can be detected after $68 \mathrm{~s}$ operation time, while a further increase of operation time to $340 \mathrm{~s}$ leads only to enhanced inactivation of one more $\log$ unit to a $\log 5$ reduction in total. The results are shown in Figure 2. The solid symbols represent the average value of the 4 replicates and the open symbols represent the standard deviation. Although the ozone concentration was found to be low (less than $2 \mathrm{ppm}$ ) a significant inactivation rate could be achieved. According to [4, 19], NO is an antimicrobial active species and contributes also to the inactivation process. Charged particles can cause cell rupture due to electrostatic forces $[4,7]$ and can contribute to the inactivation of microorganisms. Vaz-Velho et al. [20] exposed a pure culture of Listeria innocua on agar plates to ozone in a chamber (concentration approximately $50 \mathrm{ppm}$ ) and 
found a $\log 3.5$ reduction after an exposure time of $20 \mathrm{~min}$ and longer. Although the ozone concentration in the chamber increased after $20 \mathrm{~min}$, a further reduction was not observed. Although this ozone concentration was higher than the ozone concentration in our DBD where we achieved a reduction of $\log 5$ after approximately $340 \mathrm{~s}$ of operation time (37 s of exposure time) it is difficult to compare these results due to the different type of treatment. Similar experiments have been carried out by [21], where Listeria innocua cultures were exposed to an ozone atmosphere. The ozone concentration was between $50 \mathrm{ppb}$ and $100 \mathrm{ppb}$. This is less than the ozone concentration in our DBD. This might explain the rather long exposure time of $1.3 \mathrm{~h}$ at $20^{\circ} \mathrm{C}$ to obtain a $\log 2$ reduction. Critzer et al. [19] exposed Listeria monocytogenes on agar plates to the exhaust of a plasma operated in air and reported a reduction of $\log 4$ after an exposure time of $10 \mathrm{~s}$ and a further reduction of log 4.5 after an exposure time of $30 \mathrm{~s}$. In spite of the different methods (remote and direct treatment) these results are in good agreement with our results, where a reduction of $\log 4$ is achieved after $8 \mathrm{~s}$ of exposure time and a $\log 4.5$ reduction after an exposure time of $20 \mathrm{~s}$. Perni et al. [17] exposed tissues with Listeria monocytogenes directly to a low temperature discharge operated in an $\mathrm{He} / \mathrm{O}_{2}$ mixture. A reduction below the detection limit was reported after $1.5 \mathrm{~s}$. The high standard deviation in our results is most likely due to the challenging design of the experiment. We have chosen a design which is as close as possible to industrial conditions which means that more tolerance to the experimental parameters is required. One example is the variation of the distance between the electrodes during operation when one electrode is moving. Experiments at various power settings of the DBD are in progress.

\section{Conclusion}

Inactivation of Listeria innocua can efficiently be performed by direct treatment of a material by means of a DBD. A $\log 5$ reduction of Listeria innocua could be achieved on an industrial rotating cutting tool while the tool is in operation. The required operation time of the cutting tool was $340 \mathrm{~s}$. This corresponds to an effective treatment time of approximately $41 \mathrm{~s}$, because the DBD does not cover the entire cutting tool. This in turn allows applying this decontamination technique during the slicing process and provides the potential to reduce the risk of cross contamination between separate batches of meat.

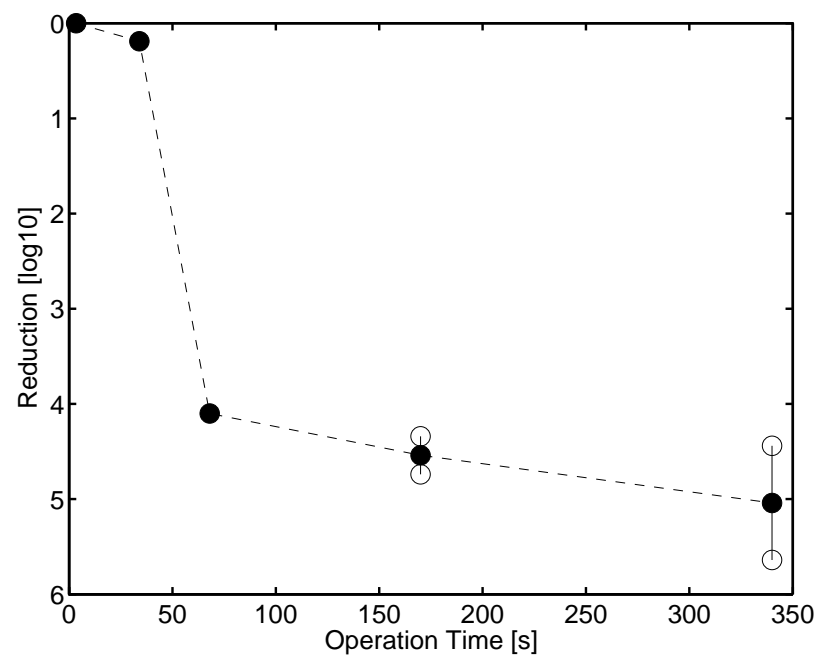

FIG. 2: Inactivation versus the operation time of the plasma. The effective exposure time of the bacteria to the plasma is $12.2 \%$ of the operation time. The solid symbols represent the average value and the open symbols represent the standard deviation

\section{Acknowledgements}

This work was funded by the Danish Meat Research Institute, project no. 18557, and the National Laboratory for Sustainable Energy, Technical University of Denmark, Funds for Innovation no. 200800423

\section{References}

[1] M. Laroussi, C. Tendero, X. Lu, S. Alla, and W. L. Hynes, Plasma Processing and Polym. 3, 470 (2006).

[2] M. Laroussi and F. Leipold, Int. J. of Mass Spectroscopy 233, 81 (2004).

[3] M. Laroussi, D. Mendis, and M. Rosenberg, New J. Phys. 5, 41.1 (2003).

[4] M. Laroussi, IEEE Trans. Plasma Sci. 30, 1409 (2002).

[5] M. Laroussi, J. P. Richardson, and F. C. Dobbs, Appl. Phys. Lett. 81, 772 (2002).

[6] M. Laroussi, G. S. Sayler, B. B. Glascock, B. McCurdy, M. E. Pearce, N. G. Bright, and C. M. Malott, IEEE Trans. Plasma Sci. 27, 34 (1999).

[7] D. A. Mendis, M. Rosenberg, and F. Azam, IEEE Trans. Plasma Sci. 28, 1304 (2000).

[8] T. C. Montie, K. Kelly-Wintenberg, and J. R. Roth, IEEE Trans. Plasma Sci. 28, 41 (2000).

[9] K. Kelly-Wintenberg, A. Hodge, T. C. Montie, L. Deleanu, D. Sherman, J. R. Roth, P. Tsai, and L. Wadsworth, J. Vac. Sci. Technol. A 17, 1539 (1999).

[10] H. W. Herrmann, I. Henins, J. Park, and G. S. Selwyn, Phys. Plasma 6, 2284 (1999).

[11] M. Laroussi, IEEE Trans. Plasma Sci. 24, 1188 (1996). 
[12] A. J. Moreira, R. D. Mansano, T. D. J. A. Pinto, R. Ruas, L. D. S. Zambon, M. V. da Silva, and P. B. Verdonck, Appl. Surf. Sci 235, 151 (2004).

[13] M. Nagatsu, F. Terashita, H. Nonaka, L. Xu, T. Nagata, and Y. Koide, Appl. Phys. Lett. 86, 211502 (2005).

[14] N. Philip, B. Saoudi, M. C. Crevier, M. Moisan, J. Barbeau, and J. Pelletier, IEEE Trans. Plasma Sci. 30, 1429 (2002).

[15] J. Feichtinger, A. Schulz, M. Walker, and U. Schumacher, Surf. Coat. Technol. 174, 564 (2003).

[16] T. Gans, M. Osiac, D. O’Connell, V. A. Kadetov, U. Czarnetzki, T. Schwarz-Selinger, H. Halfmann, and P. Awakowicz, Plasma Phys. Control. Fusion 47, A353 (2005).

[17] S. Perni, G. Shama, and M. G. Kong, J. Food Protection 71, 1619 (2008).

[18] N. J. Rowan, S. Espie, J. Harrower, J. G. Anderson, L. Marsili, and S. J. MacGregor, J. Food Protection 70, 2805 (2007).

[19] F. J. Critzer, K. Kelly-Wintenberg, S. L. South, and D. A. Golden, J. Food Protection 70, 2290 (2007).

[20] M. Vaz-Velho, F. Fonseca, M. Silva, and P. Gibbs, Food Control 12, 361 (2001).

[21] L. Fan, J. Song, K. B. Mcrae, B. A. Walker, and D. Sharpe, J. of Appl. Microbiology 103, 2657 (2007).

[22] W. N. Wade, A. J. Scouten, K. H. McWatters, R. L. Wick, A. Demirci, W. F. Fett, and L. R. Beuchat, J. Food Protection 66, 44 (2003). 